IJTAR

International Journal of Transactional Analysis Research
$7(2), 29-41$

https://doi.org/10.29044/v7i2p29

\title{
The Many Faces of Transactional Analysis: A Survey Study of the Practice and Identity of Transactional Analysis Therapists in the UK
}

\author{
(C) 2016 Siobhan Gregory
}

\begin{abstract}
An online survey method was used with a sample of 99 therapists who had completed at least 4 years of transactional analysis psychotherapy training to investigate factors including their views on the most and least practised TA psychotherapy approaches based on the 'schools' of Classical, Redecision, Cathexis, Integrative, Psychodynamic and Relational. Demographic information on gender, age, therapeutic activity and professional associations was also collected, and the survey explored subjects' willingness to diversify their knowledge of therapies other than TA, how much they integrated across therapeutic modalities, and their commitment to a TA Identity.
\end{abstract}

Statistical analysis was conducted on the TA Identity and Integrative Identity scales within the survey, which were shown to have good reliability and internal consistency. Statistical analysis of results indicated that participants displayed significantly higher levels of Integrative Identity than TA Identity, although it was not clear whether that related to the TA Integrative approach or to the general integration of different approaches. Attainment of the international TA qualification as Certified Transactional Analyst (Psychotherapy) was shown to be related to commitment to TA and commitment in the TA community.

\section{Key Words}

schools of TA, transactional analysis psychotherapy, therapist identity, integrative psychotherapy, online survey

\section{Transactional Analysis Approaches}

Transactional analysis (TA) benefits from a rich vein of theory, dating back to the nineteen fifties, which continues to evolve. The Classical school of TA is normally regarded as that based on Berne's (1961, 1966, 1972) original work, whereas the Redecision school came somewhat later and consisted of combining TA with gestalt techniques so that clients could redecide script decisions in their Child ego state (Goulding \& Goulding, 1979). At about the same time, the Cathexis school (Schiff \& Contributors, 1975) took a more radical reparenting approach and paid close attention to transforming cognitive distortions. These three were followed by Integrative (Erskine \& Trautmann, 1996; Erskine, Morsund \& Trautmann, 1999) which integrated various fields of psychotherapy whilst placing empathy and attunement at the forefront of treatment in order to meet relational needs so that clients could integrate fixated ego states, and Psychodynamic (Novellino \& Moiso, 1990; Moiso \& Novellino, 2000) which followed the Freudian foundations of Berne's original theories, concentrating on transference to achieve psychoanalytic cure. The most recent addition has been Relational TA (Hargaden \& Sills, 2002) which draws on a wide range of modern psychodynamic/psychoanalytic theory, concentrating on working with unconscious processes using various transferences in a therapeutic relationship where client and therapist fully participate.

We can consider the differences between the various schools or approaches by reference to Stark's (2000) descriptions of different psychologies. The role of the therapist within the classical, redecision, psychodynamic and some parts of the cathexis approach (correcting cognitive distortions) seems to embody what Stark described as a one-person psychology, where the therapist acts more as a neutral observer, providing interventions to increase client knowledge and move them out of psychopathology. The reparenting aspects of cathexis and the empathic attunement of integrative TA seem to reflect a one-and-a-half-person approach in which the therapist is equated to only half a person, hoping to effect change through empathy and mirroring whilst not giving away all of themselves. Relational TA 
seems to embrace a two-person approach in which the therapist and client relate to each other as real people in a real relationship, mining the depths of their respective phenomenologies.

Just as TA has the potential to be practised in different modes, it may also resemble different theoretical orientations. A TA therapist choosing elements from the classical and cathexis schools may, for example, end up practising in a similar way to a cognitive-behavioural therapist; one employing integrative TA may practice in a similar way to a person-centred therapist; and the therapist embracing a relational TA approach with aspects of classical TA may appear to work in a similar way to a therapist employing a modern (pluralistic) psychodynamic approach to therapy.

Stewart (1996, 2000) advocates an approach which integrates elements of classical, redecision and cathexis TA. Clarkson (1992) also suggests an integrated approach to TA, combining classical, redecision and cathexis elements within a traditional psychodynamic /psychoanalytic standpoint.

\section{Literature Review}

Although not related to TA, there have been previous quantitative research studies about aspects of therapists' practice. For example, Hollanders \& McLeod (1999) carried out a postal survey of over 300 British counsellors in order to uncover their tendencies towards therapy integration, finding that whilst $42 \%$ classified themselves as integrative/eclectic, up to $87 \%$ displayed some degree of integration/eclecticism in their practice. Orlinsky, Ronnestad, Gerin, Willutski et al (1999) used extensive questionnaires to gather a great deal of multinational data across 20 countries on the development and practice of nearly 3800 therapists (55\% female, average age 41 years), with the result that $54 \%$ displayed a tendency towards psychotherapy integration and did not identify with a single orientation. Cook, Biyanova, Elhai, Schnurr \& Coyne (2010) conducted an internet survey with over 2000 therapists ( $77 \%$ female, average age of 59 years) to measure client base, theoretical orientation and technique preference, with the majority claiming to identify with more than one theoretical orientation or that they had an eclectic orientation.

In the UK, although some Integrative schools exist, psychotherapy is still predominantly taught by single orientation approaches (Cooper \& Mcleod, 2011). This is reflected at a higher level by health trusts and government initiatives favouring specific approaches (e.g. evidence-based CBT) and tailored treatments for specific conditions (Department of Health, 2001). This state of play creates an unfortunate sense of competition in the psychotherapy marketplace. Hollanders (2003) has pointed to the dangers of unproductive 'schoolism': in which 'binary thinking' therapists take an oppositional stance and defend the 'truth' of their own school. Norcross (2005) comments that "therapy systems, like battling siblings, competed for attention and affection in a 'dogma eat dogma' environment (Larsen, 1980). Mutual antipathy and exchange of puerile insults between adherents of rival orientations were very much the order of the day." (p.3)

The existence of schoolism may be explained by cognitive dissonance theory (Festinger, 1957), when individuals, having invested in a particular choice, go on to feel more positively about and defend their original choice. Therapists who choose a particular orientation may have an investment in viewing it positively, in order to justify the time and energy they have invested in it (Cooper \& McLeod, 2011).

Social identity theory offers another route through which schoolism may develop, with people feeling better about themselves if they can identify positively with the in-group to which they belong (Tajfel \& Turner, 1979; Operatio \& Fiske, 2001; Dovidio \& Gaertner, 2006; Cooper \& McLeod, 2011). Larsson, Broberg \& Kaldo (2013) investigated negative stereotyping, and found that those from CBT and psychodynamic backgrounds overestimated the differences between themselves and therapists from other orientations; integrative/eclectic therapists were least likely to have stereotyped views of therapists from other orientations; and CBT therapists were the most likely to hold stereotyped views.

Norcross (2005) describes psychotherapy integration as an evolving movement that has gained considerable strength in the past 30 years. Integration is an antidote to and a reaction against entrenched schoolism, and a recognition that there are multiple routes to psychological health. Psychotherapy integration seeks to dissolve schoolism and has been brought about in part by therapists becoming disillusioned with the inadequacies of a single school approach (Garfield \& Kurtz, 1977; Norcross, Karpiak \& Lister, 2005).

As long as psychotherapy in the UK stays marked by divisions between different orientations, it seems that psychotherapy as a profession will be particularly vulnerable to schoolism. If, on the other hand, psychotherapists seek to embrace multiple orientations through integration/eclecticism, it seems they will be much less vulnerable to negatively judging fellow therapists on the basis of their chosen theoretical orientation (Larsson, Broberg \& Kaldo, 2013).

Increasingly, there is an emphasis on a pluralistic framework, which can be seen as being governed by the client's own goals for therapy, the therapist's tasks or strategies and the methods employed. Inherent in the pluralistic approach to therapy is the idea that different therapies work for different people at different points "collaborative pluralism can be regarded as an adaptation and elaboration of central themes found in other strategies for therapy integration". (McLeod, 2009 p.382), with the aim of developing "a way of practicing, researching and thinking about therapy which can embrace, as fully as possible, the whole range of 
therapeutic methods and concepts." (Cooper \& McLeod, 2011 p. 6)

Widdowson (2013) argues that TA seems well placed to position itself as a pluralistic therapy. TA therapists already embrace openness and emphasise collaboration with their clients, and benefit from being well-versed in a variety of cognitive-behavioural, humanistic, psychodynamic and relational methods and techniques. "TA, as evidenced in the case series, both conceptualises the client and promotes change in cognitive, affective, behavioural and relational domains using an integrative and coherent framework. It would appear that this is a significant (and possibly) unique contribution that TA makes to psychotherapy." (7.3.1.8)

\section{Research Question}

The study was set up to gain a deeper understanding of how TA therapists practice. The practice and identity of them was of particular interest, as was the extent to which various TA approaches are embraced, rejected and/or integrated into practice. There was also an intention to ascertain if TA therapists saw their practice as similar to that of other theoretical orientations, and whether there was a tendency for therapy integration.

\section{Ethical Approval}

This study was conducted under the auspices of an MSc program in Transactional Analysis Counselling provided by Physis Training, accredited by Queen Margaret University. Ethical approval was sought via a research proposal submitted to the MSc module leader (and University) who had overall authority for the program. Given that no clients were involved in the study and that there were no potentially sensitive or distressing survey questions, ethical approval was granted.

Survey respondents were not contacted directly and were completely anonymous. They could not withdraw once they had completed the survey but they could stop at any time during completion.

\section{Method}

Survey

An online questionnaire was devised, entitled Practice and Identity of TA Therapists, and powered by Survey Monkey (www.surveymonkey.net). A pilot study of the survey was conducted with six colleagues, feedback was received and a preliminary analysis was carried out, after which some changes were made to produce the final version (see Table 2).

Timed to take less than five minutes to complete, the first page obtained information about respondents' age, gender, years of experience as a therapist, details of the amount, type and setting of their client work, their level of TA qualification and the professional associations of which they were a member. They were also asked to rank the six TA schools in order of importance and to state which they identified with most and least. The second page of the e-survey asked respondents to indicate the extent to which they agreed with 25 statements pertaining to their practice and identity as TA therapists, using a 5 point Likert scale. The statements can be seen in Table 2.

Requests were made to all UK Association of Transactional Analysis (UKATA) registered training establishments to distribute the link to the e-survey to all previous psychotherapy trainees who had completed 4 years of TA psychotherapy training, which equated to Diploma level or above as awarded by the centres. Of these, Physis Training, Wealden Institute, Ellesmere Centre, Leeds Psychotherapy Training Institute, and the Link Centre did so. Metanoia Institute also circulated the survey, as did UKATA itself. The covering email assured respondents that all responses were entirely anonymous and confidential. The researcher's email address was given if they wished to ask any questions.

\section{Participants}

The opportunistic sample of 99 comprised 67 females and 27 males, plus 5 who declined to indicate gender. Only 90 of those responded to all of the statements in the second half of the survey. The results indicated below are therefore based on 99 responses for the first section and 90 for the second.

In addition to having completed core transactional analysis psychotherapy training, some had obtained a master's level qualification in TA and some had attained Certified Transactional Analyst (Psychotherapy) (CTA) or Teaching \& Supervising Transactional Analyst (Psychotherapy) (TSTA). All of them worked with individual clients, just over half worked with couples, and nearly a third did group work. The highest proportion of them had 1-10 year's experience and most practised 110 hours per week. The majority worked in private practice, with a small number doing voluntary or NHS work. This information about the sample is given in more detail below within the analysis of Results.

\section{Results}

Demographics

$71.3 \%$ were female and $28.7 \%$ were male.

Figure 1 shows the age distribution; Figure 2 shows years of practice; and Figure 3 indicates the level of TA qualifications held. Figure 4 indicates the settings of practice and Figure 5 shows membership of professional associations. Figures 6 and 7 show respectively the TA approaches most and least identified with, whilst Figure 8 indicates the importance rankings given to the TA schools. Table 1 contains the raw data corresponding to Figure 8.

Note that for Figures 3, 4, 5 and 8, participants were able to select more than one response

Editor's Note 1: $n=99$ so demographic raw scores are virtually identical to percentages.

Editor's Note 2: in Figure 5, members of ITA/UKATA are automatically members of EATA, so EATA membership must apply to at least 90 respondents. 


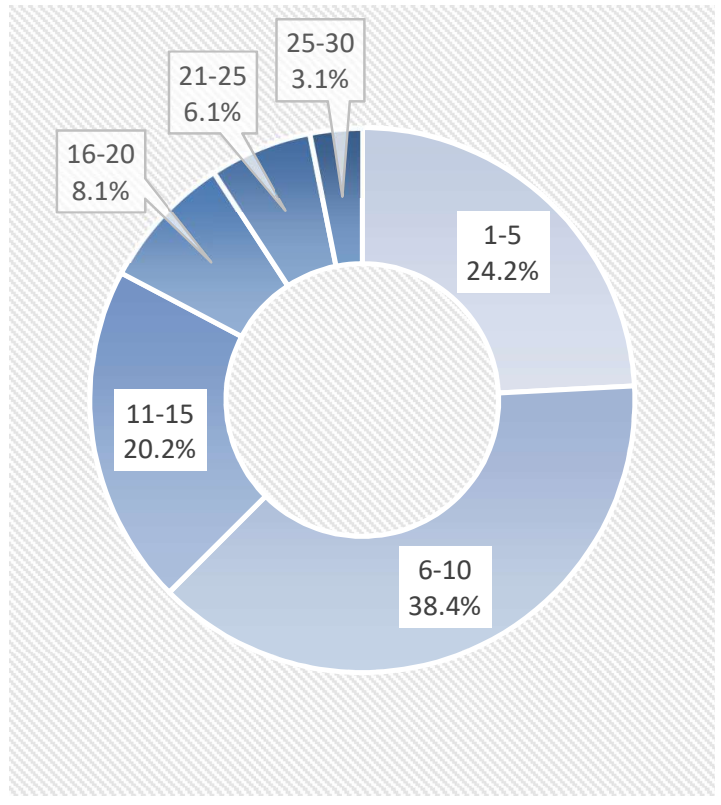

Figure 1: Age Distribution

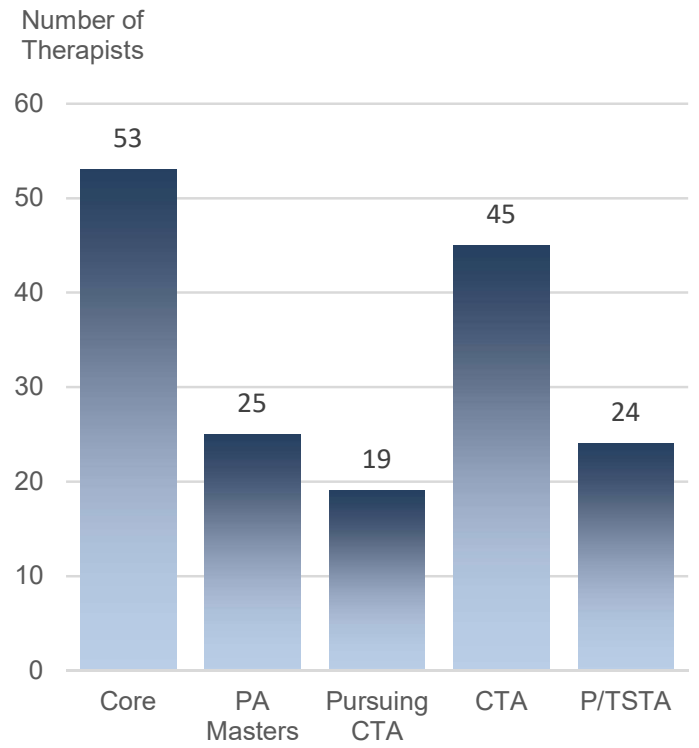

Figure 3: Level of TA Qualification

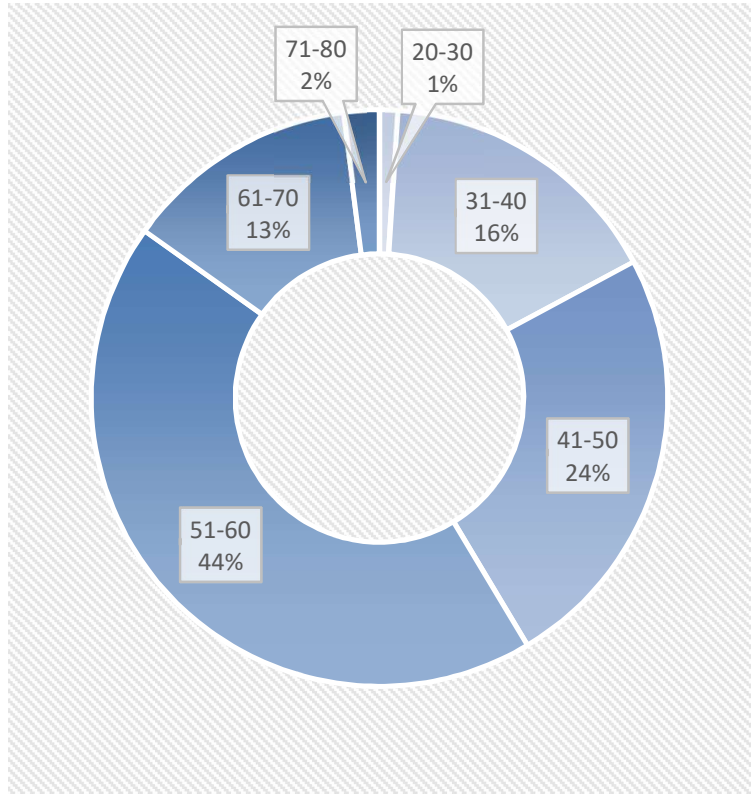

Figure 2: Years of Practice

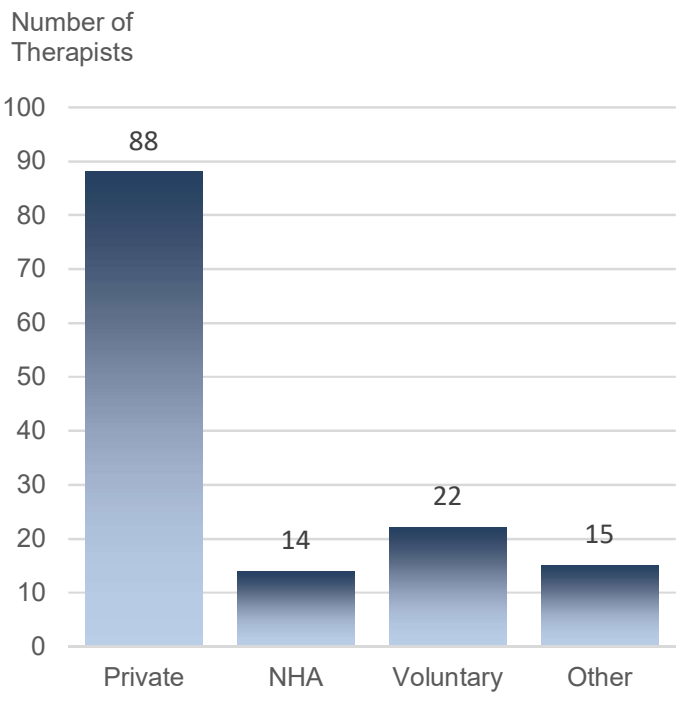

Figure 4: Setting of Therapy Practice 
Number of

Therapists

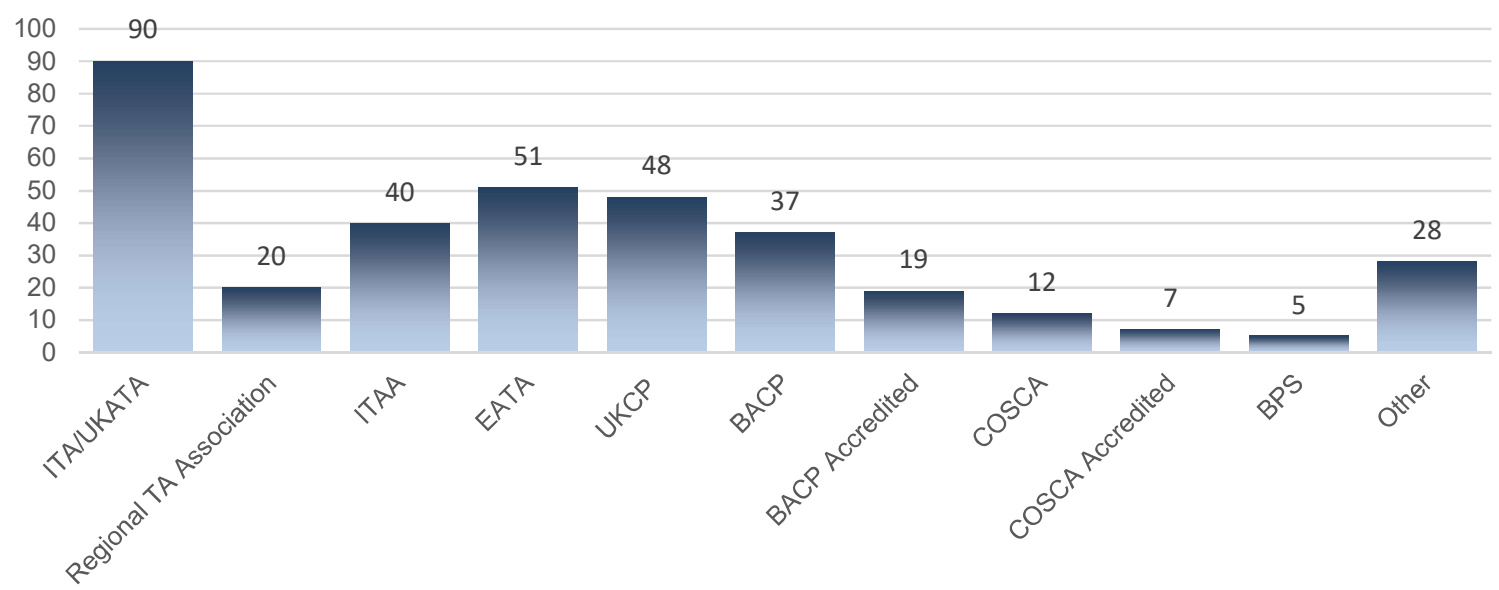

\begin{tabular}{ll}
\hline ITA/UKATA & Institute of Transactional Analysis/UK Association of Transactional Analysis \\
\hline ITAA & International Transactional Analysis Association \\
\hline EATA & European Association of Transactional Analysis \\
\hline UKCP & UK Council for Psychotherapy \\
\hline BACP & British Associations for Counselling \& Psychotherapy \\
\hline COSCA & Counselling \& Psychotherapy in Scotland \\
\hline BPS & British Psychological Society \\
\hline
\end{tabular}

Figure 5: Membership of Professional Associations

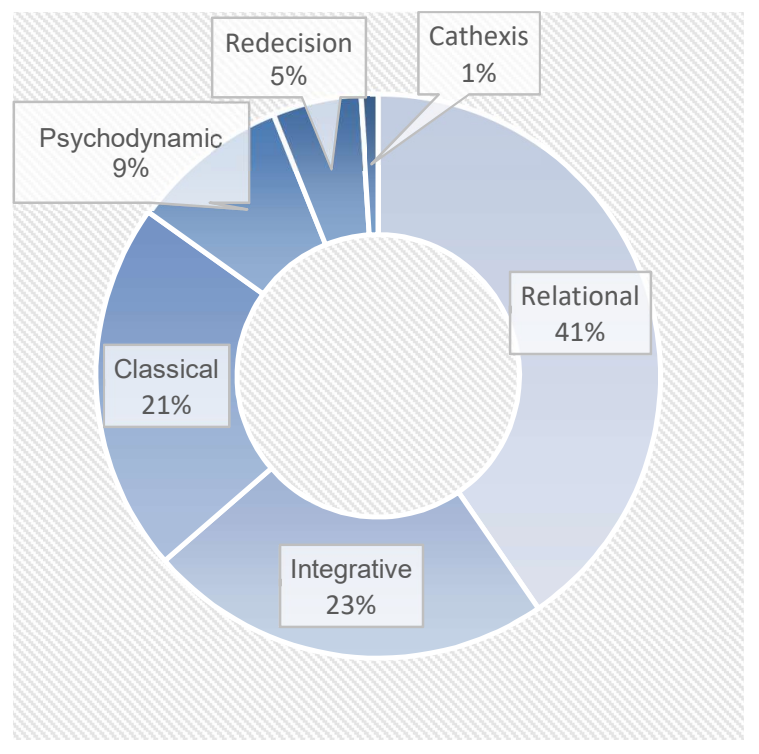

Figure 6: TA Approach Most Identified With

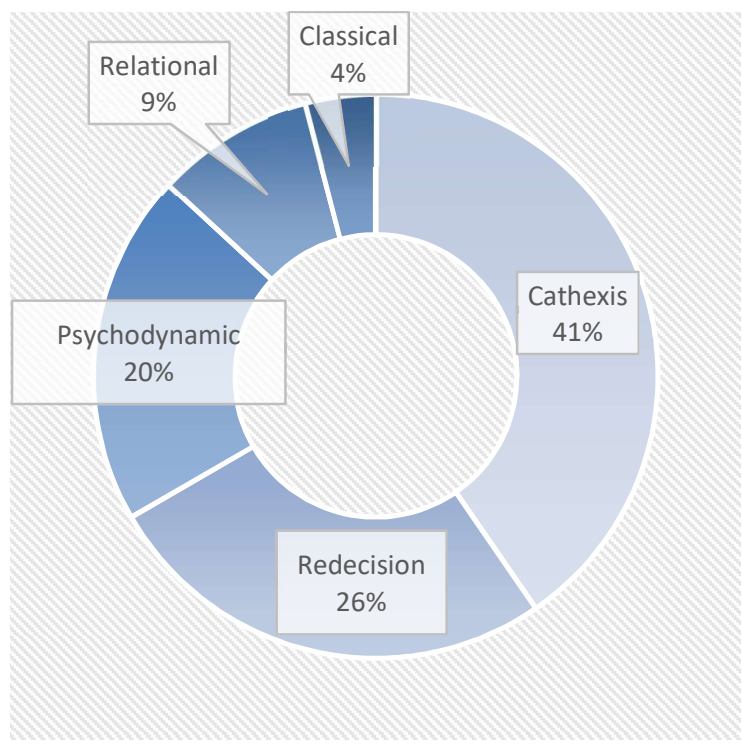

Figure 7: TA Approach Least Identified With 


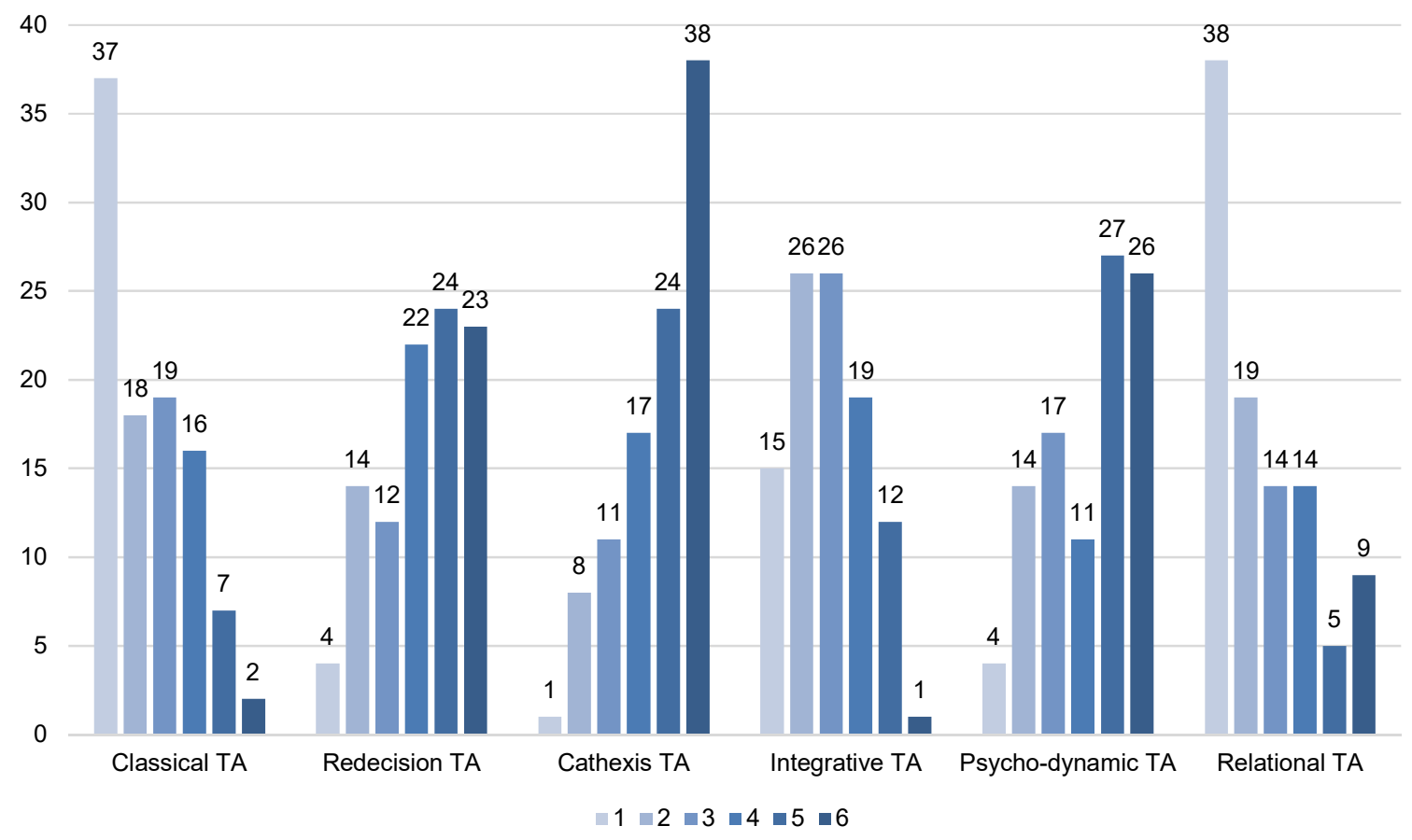

Figure 8: Ranking of TA Schools in Order of Importance

\begin{tabular}{|c|c|c|c|c|c|c|c|}
\hline & 1 & 2 & 3 & 4 & 5 & 6 & Total \\
\hline \multirow[t]{2}{*}{ Classical TA } & $37.37 \%$ & $18.18 \%$ & $19.19 \%$ & $16.16 \%$ & $7.07 \%$ & $2.02 \%$ & \\
\hline & 37 & 18 & 19 & 16 & 7 & 2 & 99 \\
\hline \multirow[t]{2}{*}{ Redecision TA } & $4.04 \%$ & $14.14 \%$ & $12.12 \%$ & $22.22 \%$ & $24.24 \%$ & $23.23 \%$ & \\
\hline & 4 & 14 & 12 & 22 & 24 & 23 & 99 \\
\hline \multirow[t]{2}{*}{ Cathexis TA } & $1.01 \%$ & $8.08 \%$ & $11.11 \%$ & $17.17 \%$ & $24.24 \%$ & $38.38 \%$ & \\
\hline & 1 & 8 & 11 & 17 & 24 & 38 & 99 \\
\hline \multirow[t]{2}{*}{ Integrative TA } & $15.15 \%$ & $26.26 \%$ & $26.26 \%$ & $19.19 \%$ & $12.12 \%$ & $1.01 \%$ & \\
\hline & 15 & 26 & 26 & 19 & 12 & 1 & 99 \\
\hline \multirow[t]{2}{*}{ Psycho-dynamic TA } & $4.04 \%$ & $14.14 \%$ & $17.17 \%$ & $11.11 \%$ & $27.27 \%$ & $26.26 \%$ & \\
\hline & 4 & 14 & 17 & 11 & 27 & 26 & 99 \\
\hline \multirow[t]{2}{*}{ Relational TA } & $38.38 \%$ & $19.19 \%$ & $14.14 \%$ & $14.14 \%$ & $5.05 \%$ & $9.09 \%$ & \\
\hline & 38 & 19 & 14 & 14 & 5 & 9 & 99 \\
\hline
\end{tabular}

Table 1: Ranking of TA Schools in Order of Importance 
Practice and Identity

24 of the 25 statements in the second part of the survey have been clustered into four categories for the purposes of presentation in Table 2: these are TA Practice, TA Identity, Integrative Identity, and Approach Similarities.

In the TA Practice category, the majority of participants $(85.8 \%)$ said they did not rely on just one TA approach. $48.4 \%$ disagreed and $37.4 \%$ strongly disagreed with the statement 'I rely on the theory and technique of one particular approach to TA.' Only one person (1.1\%) agreed with this statement. Similarly, nearly all the participants $(95.7 \%)$ agreed that they relied on a variety of techniques drawn from different approaches to TA. The majority $(92.4 \%)$ also thought of TA as an integrative therapy and $72.4 \%$ actively attempted to integrate competing TA theories in their practice.

Responses to statements about TA Identity received a mixed response. It can be seen that participation in the TA community was important to the majority $(73.7 \%)$ of participants and $87.8 \%$ had attempted to deepen their TA knowledge since completing their training. However, statements regarding Continuing Professional Development (CPD) activity showed there was no clear preference for or against CPD activities with a specific TA content and orientation. Roughly equal numbers agreed, disagreed or were neutral about having a preference for specifically TA orientated reading material, workshops, CPD activities or conferences.

When it came to responses in the Integrative Identity category, a strong tendency towards therapy integration was displayed. Overall, the vast majority (93.5\%) thought it was important to have a broad knowledge of theories and techniques from other therapeutic modalities. In addition, $87.9 \%$ had attempted to integrate techniques and theories from other therapeutic modalities in their practice with clients. Likewise, $83.3 \%$ had attempted to diversify their knowledge of other therapies since completing their TA training and $60.5 \%$ felt they had to look outside of TA to fully help their clients.

There was very little disagreement with statements regarding a preference for general CPD activities. Most participants $(61.6 \%)$ endorsed reading books and journals with a general approach to therapy. Similarly, $72.5 \%$ said they would prefer to attend activities or workshops with a diverse approach to therapy. There was some uncertainty over preferences for conferences aimed at counsellors/therapists in general; $44.5 \%$ agreed they preferred these but more $(46.7 \%)$ had a neutral response. There was also a mixed response to the statement 'My commitment to the TA approach to therapy has declined since completing my core training.' Whilst the majority (55\%) disagreed with this statement, $31.9 \%$ agreed with it and $13.2 \%$ had a neutral response.

When it came to statements regarding TA's similarities to other approaches, the clear majority $(90 \%)$ felt that their way of working shared many similarities with a humanistic approach to therapy. Likewise, $85.7 \%$ felt that their way of working shared many similarities with an integrative/eclectic approach to therapy. There was no disagreement with either of these statements. Participants had less certainty that their way of working with clients shared many similarities with a CBT approach; only $2.2 \%$ strongly agreed with this statement and $35.6 \%$ agreed, $26.7 \%$ had a neutral response, $28.9 \%$ disagreed and $6.7 \%$ disagreed strongly. Participants had slightly more agreement ( $55 \%$ overall) that their way of working shared many similarities with a psychodynamic approach to therapy, 31.9\% had a neutral response and $13.2 \%$ overall disagreed.

\section{Statistical Analysis}

As previously mentioned, only 90 participants responded to all statements. Given that a minimum of 100 participants are needed for factor analysis, it could not be carried out in the present study. Had there been a larger sample, it would have been optimal to use this tool to test for underlying dimensions measured by the statement questions. As an alternative to this, the four statement categories in Table 2 underwent reliability analysis using Cronbach's Alpha. It was found that the 8 statements in the TA Identity category correlated well with one another, showing good internal consistency and reliability with a high alpha of 0.87 . The 8 statements can be said to effectively measure TA Identity and give credibility to TA Identity being a reliable subscale. There was a similar result for the 8 items in the Integrative Identity category, showing it to be a reliable subscale. This subscale originally contained 9 statements but it was shown that a higher alpha of 0.79 could be obtained if the statement 'Participation in the wider therapy community is important to me.' was deleted.

On average, participants' mean Integrative Identity scores $(M=3.74, S D=0.51)$ were higher than their mean TA Identity scores $(M=3.28, S D=0.60)$. A paired samples t-test was carried out to test if these differences were significant. The results $(\mathrm{t}(90)=4.31, \mathrm{p}=0.00,2$ tailed) confirmed that participants displayed significantly higher levels of Integrative Identity than TA Identity.

To investigate whether differences in therapy identity were tempered by level of TA qualification, a number of independent samples t-tests were carried out. These looked at whether having CTA had any bearing on various aspects of TA/Integrative Identity. It was found that on average, participants with CTA (M $=4.2, \mathrm{SD}=$ 0.72 ) had greater agreement with the statement 'I am committed to the TA approach to therapy.' than those without CTA $(\mathrm{M}=3.88, \mathrm{SD}=0.71)$. An independent samples t-test confirmed that participants who had attained CTA showed significantly higher levels of commitment to the TA approach to therapy than those who had not $(t(89)=2.099, p=0.039,2$-tailed $)$.

Participants with CTA also seemed to agree more $(\mathrm{M}=$ $4.41, S D=0.68)$ than participants without CTA $(M=3.90$, $\mathrm{SD}=0.76)$ that they had attempted to deepen their TA 


\begin{tabular}{|c|c|c|c|c|c|c|c|}
\hline $\begin{array}{l}\text { Statement } \\
\text { category }\end{array}$ & Statement & $\begin{array}{l}\text { Strongly } \\
\text { Agree }\end{array}$ & Agree & Neutral & Disagree & $\begin{array}{l}\text { Strongly } \\
\text { Disagree }\end{array}$ & $\begin{array}{l}\text { Total } \\
\text { responses }\end{array}$ \\
\hline \multirow[t]{4}{*}{$\begin{array}{l}\text { TA Therapy } \\
\text { Integration }\end{array}$} & $\begin{array}{l}\text { 12. 'I rely on the theory and } \\
\text { technique of one particular } \\
\text { approach to TA.' }\end{array}$ & $\begin{array}{l}0 \% \\
(0)\end{array}$ & $\begin{array}{r}1.1 \% \\
(1)\end{array}$ & $\begin{array}{r}13.2 \% \\
(12)\end{array}$ & $\begin{array}{r}48.4 \% \\
(44)\end{array}$ & $\begin{array}{r}37.4 \% \\
(34)\end{array}$ & 91 \\
\hline & $\begin{array}{l}\text { 13. 'I rely on a variety of } \\
\text { techniques from different } \\
\text { approaches to TA.' }\end{array}$ & $\begin{array}{r}51.7 \% \\
(47)\end{array}$ & $\begin{array}{l}44 \% \\
(40)\end{array}$ & $\begin{array}{r}2.2 \% \\
(2)\end{array}$ & $\begin{array}{r}1.1 \% \\
(1)\end{array}$ & $\begin{array}{r}1.1 \% \\
(1)\end{array}$ & 91 \\
\hline & $\begin{array}{l}\text { 14. 'I try to integrate } \\
\text { competing TA theories.' }\end{array}$ & $\begin{array}{r}19.8 \% \\
(18)\end{array}$ & $\begin{array}{l}55 \% \\
(50)\end{array}$ & $\begin{array}{l}22 \% \\
(20)\end{array}$ & $\begin{array}{r}3.3 \% \\
(3)\end{array}$ & $\begin{array}{l}0 \% \\
(0)\end{array}$ & 91 \\
\hline & $\begin{array}{l}\text { 21. 'I think TA is an integrative } \\
\text { therapy.' }\end{array}$ & $\begin{array}{r}37.4 \% \\
(34)\end{array}$ & $\begin{array}{l}55 \% \\
(50)\end{array}$ & $\begin{array}{r}5.5 \% \\
(5)\end{array}$ & $\begin{array}{r}2.2 \% \\
(2)\end{array}$ & $\begin{array}{l}0 \% \\
(0)\end{array}$ & 91 \\
\hline \multirow[t]{8}{*}{ TA Identity } & $\begin{array}{l}\text { 22. 'TA is all I need to help my } \\
\text { clients.' }\end{array}$ & $\begin{array}{r}2.2 \% \\
(2)\end{array}$ & $\begin{array}{r}5.5 \% \\
(5)\end{array}$ & $\begin{array}{r}17.8 \% \\
(16)\end{array}$ & $\begin{array}{r}56.7 \% \\
(51)\end{array}$ & $\begin{array}{r}17.8 \% \\
(16)\end{array}$ & 90 \\
\hline & $\begin{array}{l}\text { 24. 'I am committed to a TA } \\
\text { approach to therapy.' }\end{array}$ & $\begin{array}{r}24.2 \% \\
(22)\end{array}$ & $\begin{array}{l}56 \% \\
(51)\end{array}$ & $\begin{array}{r}16.5 \% \\
(15)\end{array}$ & $\begin{array}{r}3.3 \% \\
(3)\end{array}$ & $\begin{array}{l}0 \% \\
(0)\end{array}$ & 91 \\
\hline & $\begin{array}{l}\text { 26. 'I prefer to read books and } \\
\text { journal articles that are } \\
\text { specifically related to TA.' }\end{array}$ & $\begin{array}{r}1.1 \% \\
(1)\end{array}$ & $\begin{array}{r}21.1 \% \\
(19)\end{array}$ & $\begin{array}{r}34.4 \% \\
(31)\end{array}$ & $\begin{array}{r}34.4 \% \\
(31)\end{array}$ & $\begin{array}{r}8.9 \% \\
(8)\end{array}$ & 90 \\
\hline & $\begin{array}{l}\text { 28. 'I prefer to attend CPD's or } \\
\text { workshops that are led by } \\
\text { trainers with a TA approach to } \\
\text { therapy.' }\end{array}$ & $\begin{array}{r}2.2 \% \\
(2)\end{array}$ & $\begin{array}{r}33.3 \% \\
(30)\end{array}$ & $\begin{array}{l}30 \% \\
(27)\end{array}$ & $\begin{array}{r}33.3 \% \\
(30)\end{array}$ & $\begin{array}{r}1.1 \% \\
(1)\end{array}$ & 90 \\
\hline & $\begin{array}{l}\text { 29. 'I prefer to attend CPD's or } \\
\text { workshops that specifically } \\
\text { relate to a TA approach to } \\
\text { therapy.' }\end{array}$ & $\begin{array}{r}1.1 \% \\
(1)\end{array}$ & $\begin{array}{r}27.8 \% \\
(25)\end{array}$ & $\begin{array}{r}32.2 \% \\
(29)\end{array}$ & $\begin{array}{r}35.6 \% \\
(32)\end{array}$ & $\begin{array}{r}3.3 \% \\
(3)\end{array}$ & 90 \\
\hline & $\begin{array}{l}\text { 31. 'I prefer to attend } \\
\text { conferences that are } \\
\text { specifically aimed at TA } \\
\text { therapists.' }\end{array}$ & $\begin{array}{r}7.7 \% \\
(7)\end{array}$ & $\begin{array}{r}39.6 \% \\
(36)\end{array}$ & $\begin{array}{r}28.6 \% \\
(26)\end{array}$ & $\begin{array}{r}20.9 \% \\
(19)\end{array}$ & $\begin{array}{r}3.3 \% \\
(3)\end{array}$ & 91 \\
\hline & $\begin{array}{l}\text { 33. 'Since completing my core } \\
\text { TA training I have attempted to } \\
\text { deepen my knowledge of TA.' }\end{array}$ & $\begin{array}{l}30 \% \\
(27)\end{array}$ & $\begin{array}{r}57.8 \% \\
(52)\end{array}$ & $\begin{array}{r}6.7 \% \\
(6)\end{array}$ & $\begin{array}{r}5.6 \% \\
(5)\end{array}$ & $\begin{array}{l}0 \% \\
(0)\end{array}$ & 90 \\
\hline & $\begin{array}{l}\text { 36. 'Participation in the TA } \\
\text { community is important to me.' }\end{array}$ & $\begin{array}{r}20.9 \% \\
(19)\end{array}$ & $\begin{array}{r}52.8 \% \\
(48)\end{array}$ & $\begin{array}{l}22 \% \\
(20)\end{array}$ & $\begin{array}{r}3.3 \% \\
(3)\end{array}$ & $\begin{array}{r}1.1 \% \\
(1)\end{array}$ & 91 \\
\hline \multirow[t]{2}{*}{$\begin{array}{l}\text { Integrative } \\
\text { Identity }\end{array}$} & $\begin{array}{l}\text { 15. 'In my work with clients, I } \\
\text { try to integrate theories and } \\
\text { techniques from other } \\
\text { therapeutic modalities.' }\end{array}$ & $\begin{array}{r}28.6 \% \\
(26)\end{array}$ & $\begin{array}{r}59.3 \% \\
(54)\end{array}$ & $\begin{array}{r}9.9 \% \\
(9)\end{array}$ & $\begin{array}{r}2.2 \% \\
(2)\end{array}$ & $\begin{array}{l}0 \% \\
\text { (0) }\end{array}$ & 91 \\
\hline & $\begin{array}{l}\text { 20. 'I think it is important to } \\
\text { have a broad knowledge of } \\
\text { techniques and theories from } \\
\text { different approaches to } \\
\text { therapy.' }\end{array}$ & $\begin{array}{r}40.7 \% \\
(37)\end{array}$ & $\begin{array}{r}52.8 \% \\
(48)\end{array}$ & $\begin{array}{r}5.5 \% \\
(5)\end{array}$ & $\begin{array}{r}1.1 \% \\
(1)\end{array}$ & $\begin{array}{l}0 \% \\
\text { (0) }\end{array}$ & 91 \\
\hline
\end{tabular}




\begin{tabular}{|c|c|c|c|c|c|c|c|}
\hline $\begin{array}{l}\text { Statement } \\
\text { category }\end{array}$ & Statement & $\begin{array}{l}\text { Strongly } \\
\text { Agree }\end{array}$ & Agree & Neutral & Disagree & $\begin{array}{l}\text { Strongly } \\
\text { Disagree }\end{array}$ & $\begin{array}{l}\text { Total } \\
\text { responses }\end{array}$ \\
\hline & $\begin{array}{l}\text { 23. 'I need to look to } \\
\text { approaches outside of TA to } \\
\text { fully help my clients.' }\end{array}$ & $\begin{array}{r}18.7 \% \\
(17)\end{array}$ & $\begin{array}{r}41.8 \% \\
(38)\end{array}$ & $\begin{array}{r}26.4 \% \\
(24)\end{array}$ & $\begin{array}{r}12.1 \% \\
(11)\end{array}$ & $\begin{array}{r}1.1 \% \\
(1)\end{array}$ & 91 \\
\hline & $\begin{array}{l}\text { 25. 'My commitment to the TA } \\
\text { approach to therapy has } \\
\text { declined since completing my } \\
\text { core training.' }\end{array}$ & $\begin{array}{l}11 \% \\
(11)\end{array}$ & $\begin{array}{r}20.9 \% \\
(19)\end{array}$ & $\begin{array}{r}13.2 \% \\
(12)\end{array}$ & $\begin{array}{r}44 \% \\
(40)\end{array}$ & $\begin{array}{r}11 \% \\
(10)\end{array}$ & 91 \\
\hline \multirow[t]{4}{*}{$\begin{array}{l}\text { Integrative } \\
\text { Identity }\end{array}$} & $\begin{array}{l}\text { 27. 'I prefer to read books and } \\
\text { journal articles that are related } \\
\text { to therapy in general.' }\end{array}$ & $\begin{array}{l}11 \% \\
(10)\end{array}$ & $\begin{array}{r}50.6 \% \\
(46)\end{array}$ & $\begin{array}{r}35.2 \% \\
(32)\end{array}$ & $\begin{array}{r}3.3 \% \\
\text { (3) }\end{array}$ & $\begin{array}{l}0 \% \\
(0)\end{array}$ & 91 \\
\hline & $\begin{array}{l}\text { 30. 'I prefer to attend CPD's or } \\
\text { workshops with a diverse } \\
\text { approach to therapy.' }\end{array}$ & $\begin{array}{r}14.3 \% \\
(13)\end{array}$ & $\begin{array}{r}58.2 \% \\
(53)\end{array}$ & $\begin{array}{r}24.2 \% \\
(22)\end{array}$ & $\begin{array}{r}3.3 \% \\
(3)\end{array}$ & $\begin{array}{l}0 \% \\
(0)\end{array}$ & 91 \\
\hline & $\begin{array}{l}\text { 32. 'I prefer to attend } \\
\text { conferences that are aimed at } \\
\text { counsellors or therapists in } \\
\text { general.' }\end{array}$ & $\begin{array}{r}7.8 \% \\
(7)\end{array}$ & $\begin{array}{r}36.7 \% \\
(33)\end{array}$ & $\begin{array}{r}46.7 \% \\
(42)\end{array}$ & $\begin{array}{r}8.9 \% \\
(8)\end{array}$ & $\begin{array}{l}0 \% \\
(0)\end{array}$ & 90 \\
\hline & $\begin{array}{l}\text { 34. 'Since completing my core } \\
\text { training, I have attempted to } \\
\text { diversify my knowledge of } \\
\text { other therapies.' }\end{array}$ & $\begin{array}{r}31.1 \% \\
(28)\end{array}$ & $\begin{array}{r}52.2 \% \\
(47)\end{array}$ & $\begin{array}{r}13.3 \% \\
(12)\end{array}$ & $\begin{array}{r}3.3 \% \\
(3)\end{array}$ & $\begin{array}{l}0 \% \\
(0)\end{array}$ & 90 \\
\hline \multirow[t]{4}{*}{$\begin{array}{l}\text { Approach } \\
\text { Similarities }\end{array}$} & $\begin{array}{l}\text { 16. 'My way of working with } \\
\text { clients shares many } \\
\text { similarities with a CBT } \\
\text { approach to therapy.' }\end{array}$ & $\begin{array}{r}2.2 \% \\
(2)\end{array}$ & $\begin{array}{r}35.6 \% \\
(32)\end{array}$ & $\begin{array}{r}26.7 \% \\
(24)\end{array}$ & $\begin{array}{r}28.9 \% \\
(26)\end{array}$ & $\begin{array}{r}6.7 \% \\
(6)\end{array}$ & 90 \\
\hline & $\begin{array}{l}\text { 17. 'My way of working with } \\
\text { clients shares many } \\
\text { similarities with a } \\
\text { psychodynamic approach to } \\
\text { therapy.' }\end{array}$ & $\begin{array}{r}8.8 \% \\
(8)\end{array}$ & $\begin{array}{r}46.2 \% \\
(42)\end{array}$ & $\begin{array}{r}31.9 \% \\
(29)\end{array}$ & $\begin{array}{r}12.1 \% \\
(11)\end{array}$ & $\begin{array}{r}1.1 \% \\
(1)\end{array}$ & 91 \\
\hline & $\begin{array}{l}\text { 18. 'My way of working with } \\
\text { clients shares many } \\
\text { similarities with a humanistic } \\
\text { approach to therapy.' }\end{array}$ & $\begin{array}{r}28.9 \% \\
(26)\end{array}$ & $\begin{array}{r}61.1 \% \\
(55)\end{array}$ & $\begin{array}{r}10 \% \\
(9)\end{array}$ & $\begin{array}{l}0 \% \\
\text { (0) }\end{array}$ & $\begin{array}{l}0 \% \\
\text { (0) }\end{array}$ & 90 \\
\hline & $\begin{array}{l}\text { 19. 'My way of working with } \\
\text { clients shares many } \\
\text { similarities with an } \\
\text { integrative/eclectic approach } \\
\text { to therapy.' }\end{array}$ & $\begin{array}{r}29.7 \% \\
(27)\end{array}$ & $\begin{array}{l}56 \% \\
(51)\end{array}$ & $\begin{array}{r}14.3 \% \\
(13)\end{array}$ & $\begin{array}{l}0 \% \\
(0)\end{array}$ & $\begin{array}{l}0 \% \\
(0)\end{array}$ & 91 \\
\hline
\end{tabular}

Table 2: Participants' agreement with categorised statements 
knowledge since completing their training. An independent samples t-test confirmed that participants with CTA displayed significantly more agreement than those without CTA $(t(88)=3.307, p=0.001$, 2-tailed $)$.

Within the Integrative Identity subscale, participants with CTA $(M=4.33, S D=0.66)$ seemed to show higher levels of agreement with the statement 'Since completing my core training, I have attempted to diversify my knowledge of other therapies.' than participants without CTA ( $\mathrm{M}=$ 3.92, $\mathrm{SD}=0.77)$. An independent samples t-test confirmed that participants with CTA displayed significantly more agreement than those without CTA $(\mathrm{t}(88)=2.667, \mathrm{p}=0.009$, 2-tailed $)$.

Finally, it seemed that participants with CTA showed more agreement $(M=4.15, S D=0.70)$ than those without CTA $(M=3.75, S D=0.74)$ that participation in the TA community was important to them. An independent samples t-test confirmed that the differences were significant, showing that participation in the TA community was significantly more important to those who had attained CTA than those who had not $(t(89)=2.644, p=0.01,2$-tailed $)$.

In order to investigate whether differences in mean TA Identity and Integrative Identity scores were tempered by participant's preferred TA approach, one-way ANOVAS were carried out. Participants were split into 6 groups on the basis of the TA approach they identified with most. It was found that mean Integrative Identity scores did not differ significantly across the 6 groups. Preferred TA approach did not seem to have a significant impact on mean Integrative Identity scores. In contrast, a one-way between subjects ANOVA revealed that participants' preferred TA approach did have an impact on mean TA Identity scores, as these scores differed significantly across the 6 groups: $F(5,85)=2.993, p=0.015$.

In order to investigate if there was an interactive relationship between CTA attainment, preferred TA approach and mean TA Identity, a 2-way betweensubjects $(2 \times 6)$ ANOVA was carried out and no significant interactions were found. This shows that participants' preferred TA approach had a significant impact on their TA Identity irrespective of whether they had attained CTA or not.

Independent samples t-tests were carried out to investigate where exactly the differences in the 6 groups of preferred TA approach occurred. Mean TA Identity scores of participants preferring classical TA $(M=3.61$, $S D=0.597)$ seemed higher than those of participants preferring relational $\mathrm{TA}(\mathrm{M}=3.11, \mathrm{SD}=0.597)$ and psychodynamic TA (M = 2.87, SD = 0.554). Independent samples t-tests confirmed that participants who identified most with classical TA had significantly higher mean TA Identity scores than participants who identified most with relational TA $(t(57)=3.261, p=0.002$, 2-tailed $)$ and psychodynamic TA $(\mathrm{t}(26)=3.269, \mathrm{p}=0.003,2$-tailed) respectively. Therefore, various aspects of TA identity were significantly more important to participants who preferred classical TA than participants who preferred relational TA or psychodynamic TA.

Looking more specifically at one particular aspect of TA Identity, commitment to TA, a one way ANOVA revealed there were significant differences across the 6 groups of preferred TA approach $(F(5,85)=3.301, p=0.009)$. As previously mentioned, significant differences in commitment to TA were found between participants who had and had not attained CTA. In order to investigate if there was an interactive relationship between CTA attainment, preferred TA approach and scores measuring TA commitment, a 2-way between-subjects (2 $x$ 6) ANOVA's was carried out. The main effect of preferred TA approach was significant $(F(5,80)=2.968$, $p=0.001)$. The main effect of whether participants had attained CTA or not was very close but not significant at the $p<0.05$ level $(F(1,80=3.641, p=0.06)$. There was no significant interaction between the factor of CTA attainment and preferred TA approach $(F(4,80)=0.885$, $p>0.05)$. This shows that participants' preferred TA approach had a significant impact on their commitment to TA irrespective of whether they had attained CTA or not.

Independent samples t-tests were carried out to investigate where exactly the differences in the 6 groups of preferred TA approach occurred. Mean scores measuring commitment to TA of participants preferring classical TA ( $M=4.48, S D=0.512)$ seemed higher than those of participants preferring relational $T A(M=3.79$, $\mathrm{SD}=0.741)$ and psychodynamic $\mathrm{TA}(\mathrm{M}=3.86, \mathrm{SD}=$ 0.69). Independent samples t-tests confirmed that participants who identified most with classical TA had significantly higher mean TA Identity scores than participants who identified most with relational TA (t(57) $=3.772, p=0.00,2$-tailed)and psychodynamic TA ( $t(26)$ $=2.542, p=0.017,2$-tailed) respectively. Therefore, participants who identified most with classical TA displayed significantly higher levels of commitment to TA than participants who identified most with relational TA and psychodynamic TA.

\section{Discussion}

It was clear to see that some branches of TA were more popular than others. Relational TA was the TA approach that participants identified with most, with over $40 \%$ choosing it. Integrative TA was the second most popular TA approach, with $23.2 \%$ saying that they identified with this most. Integrative TA was closely followed by classical TA with $21.2 \%$ saying they preferred this approach. It is unclear here whether participants choosing integrative TA as their preferred approach were declaring their allegiance to Erskine's integrative TA, or whether they were showing a preference for integrating TA theories in a general way.

It was shown that participants' preferred TA approach had a bearing on the extent to which they identified with TA. For example, participants who identified most with classical TA displayed significantly higher levels of TA 
Identity than participants who identified most with relational TA or psychodynamic TA.

The level of TA qualification reached had a bearing on TA identity. Commitment to TA was found to be significantly higher, with a greater tendency towards deepening their TA knowledge post-training, by those who had attained CTA. Participation in the TA community also seemed to be mediated by CTA attainment. However, the greatest predictor of TA Identity levels was TA approach preference. The fact that participants choosing classical TA had higher levels of commitment to TA and TA Identity might be attributed to classical TA being the more traditional or grassroots level of TA. It is possible that people with a preference for relational TA have their identity more invested in relational TA circles (there is a growing IARTA - International Association of Relational TA - membership). Alternatively, they may identify more as integrative therapists. Only one person chose cathexis TA as the approach they identified with most and over $40 \%$ chose it as the approach they identified with least. Redecision TA did not fare much better, with only $5 \%$ saying they identified with this approach most and $26.3 \%$ saying they identified least with this approach.

Encouragingly, the present study found that the TA therapists surveyed displayed high levels of psychotherapy integration. The therapists surveyed showed a tendency to integrate theories and techniques from competing schools within TA. Overwhelmingly, therapists rejected the idea of using one particular TA approach in their practice., and instead endorsed employing a variety of techniques and theories across multiple approaches to TA. General therapy integration was also endorsed and practiced by the vast majority, with about $85 \%$ believing their way of working shared many similarities with an integrative/eclectic approach to therapy. These results are compatible with the research reported above in terms of integrative/eclectic approaches (Hollanders \& McLeod, 1999; Orlinsky et al, 1999; Cook et al, 2010; Norcross et al, 2005).

The endorsement of general psychotherapy integration was reflected in respondents' endorsement of CPD activities. With the exception of conferences, CPD activities which took a general/integrative approach were more readily endorsed than those that had a specific TA orientation. Indeed, when composite measures of Integrative Identity and TA Identity were taken, the therapists surveyed displayed significantly higher levels of Integrative Identity than TA Identity. Furthermore, whilst levels of TA Identity fluctuated significantly on the basis of preferred TA approach, Integrative Identity levels remained high regardless of participants' preferred TA approach. Once training has finished, there is perhaps a tendency to look outside of TA, to diversify knowledge. It may be important for therapists to immunise themselves against becoming isolated, stagnant practitioners. Varied CPD activities with varied practitioners can be rejuvenating and stimulate more thoughtful practice. The present study's results suggest there is something universal about the tendency towards integration.

It is noteworthy that one group of participants who showed high levels of commitment to TA, participation in the TA community and high levels of general TA identity were those who had attained CTA. However, alongside this strong identification with TA, these participants (who had attained CTA) also showed a significantly higher tendency than those without CTA to diversify their knowledge of therapies outwith TA. This suggests that even those strongly identified with single orientation approaches are open to therapy integration. There is also a possibility that the popularity of relational TA is linked to the endorsement of integration. Relational TA is an approach that is forward facing and inherently integrative, acknowledging as it does the contributions of neuroscience, attachment research, object relations, ego psychology and self psychology.

\section{Limitations}

Although the survey had a significant sample size, it was evident that respondents had attained different levels of TA qualifications and were therefore not homogeneous in this respect so the sample sizes for the different levels were correspondingly smaller. Designing the survey to ensure that it would not take too long to complete meant that more nuanced information on the intricacies of practice/identity could not be obtained.

Once the survey had been completed, it became clear that certain elements could have been improved upon. For example, when participants were asked to select which TA approach they identified with most it was unclear whether those selecting integrative TA were doing so because they identified with Erskine et al's (1999) brand of integrative TA. Participants may instead have been indicating a preference for integrating various TA theories and concepts in a general way. The same could be said of psychodynamic TA; participants may not have been indicating their preference for Novellino \& Moiso's (1990) brand of TA. They may instead have been indicating a preference for practising TA in a similar way to modern psychodynamic therapy. In hindsight, this could have been avoided by putting the key authors associated with each TA approach in brackets beside the approach.

Another drawback of the survey was that the user interface for the question asking participants to rank the TA approaches in order of importance from 1 to 6 was quite clumsy and confusing for some participants. For around $20 \%$ of participants, their ranking of approaches did not match up to the approaches they said they identified with most/least. This meant that the data for this question was deemed unreliable and excluded from further analysis.

The author/researcher has herself undergone the TA training and processes of identification that were being explored in this study, which may of course have biased the design of the questionnaire and the interpretation of the results. 


\section{Conclusion}

Part of the motivation for the present study was to get a clearer idea of what TA therapy consists of, given the vast array of approaches, theories and techniques available to therapists, both within and outside TA. The majority of TA therapists in the survey believed their way of working was similar to an integrative approach to therapy. In addition to this, $90 \%$ felt their way of working was similar to a humanistic approach to therapy; $55 \%$ agreed their way of working shared many similarities with a psychodynamic approach; $37.8 \%$ said their way of working shared many similarities with a CBT approach.

These results suggest that most participants see TA as a humanistic therapy, consistent with its ethos that people are OK and capable of change. The fact that there was weaker support for therapists seeing their way of working as comparable to CBT may reflect a greater reliance on relational ways of working. Alternatively, for those therapists practicing classical TA, there may be some negative stereotyping of CBT occurring. There could also be an unwillingness to see the many commonalities between a classical TA and CBT approach.

In contrast to the relatively low levels of endorsement of commonalities between TA and CBT practice, the therapists surveyed seemed surer that their way of working shared many similarities with a psychodynamic approach to therapy. This may reflect the commonalities between psychodynamic therapy and TA, particularly for those practicing classical and relational TA. As previously mentioned, relational TA has harnessed many key theories and developments from the world of psychodynamic and psychoanalytic therapy.

It is hoped that others may wish to copy the methodology of this study in order to build up an ever more detailed understanding of the practice and identity of transactional analysis therapists. The use of an online survey makes it particularly easy to access significant samples of subjects, in a convenient and low-cost manner.

Siobhan Gregory, BSc (Hons) Psych, MSc Transactional Analysis Counselling can be contacted on stauffercat@hotmail.com

\section{References}

Berne, E. (1961) Transactional Analysis in Psychotherapy. New York: Grove Press

Berne, E. (1966) Principles of Group Treatment. Menlo Park: CA

Berne, E. (1972) What Do You Say After You Say Hello? London: Corgi.

Clarkson, P. (1992). Transactional Analysis Psychotherapy: An Integrated Approach. London: Routledge.

Cook, J. M., Biyanova, T., Elhai, J., Schnurr, P. P., \& Coyne, J. C. (2010). What Do Psychotherapists Really Do In Practice? An Internet Study of Over 2,000 Practitioners. Psychotherapy Theory, Research, Practice, Training, 47(2), 260-267.
Cooper, M. \& McLeod, J. (2011). Pluralistic counselling and Psychotherapy. London: Sage.

Department of Health (2001). Treatment choices in psychological therapies and counselling. London: Department of Health. In Cooper, M. \& McLeod, J. (2011). Pluralistic counselling and Psychotherapy. London: Sage.

Dovidio, J. F. \& Gaertner, S. L. (2006). A multilevel perspective on prejudice: Crossing disciplinary boundaries. In P. A. M. Van Lange (Ed.),Bridging social psychology: Benefits of transdisciplinary approaches (pp. 385-390). Mahwah: Lawrence Erlbaum. In Larsson, B. P. M., Broberg, A. G. \& Kaldo, V. (2013). Do psychotherapists with different theoretical orientations stereotype or prejudge each other? Journal of Contemporary Psychotherapy, 43, 169-178.

Erskine, R. G., Moursund, J. P. \& Trautman, R. L. (1999) Beyond Empathy: A Therapy of Contact-in-Relationship. New York: Brunner-Routledge.

Erskine, R. G. \& Trautman, R. L. (1996) Methods of an Integrative Psychotherapy. Transactional Analysis Journal, 26(4): 316-28

Festinger, Leon (1957). A theory of cognitive dissonance. Evanston, IL: Row, Peterson

Goulding, M. M. \& Goulding, R. L. (1979) Changing Lives Through Redecision Therapy. New York: Grove Press

Garfield, S. L. \& Kurtz, R. (1977). A study of eclectic views. Journal of Clinical and Consulting Psychology,45, 78-83. In Norcross, J. C. (2005). A Primer on Psychotherapy Integration. In J. C. Norcross \& M. R. Goldfried (Eds.), Handbook of psychotherapy integration (pp. 3-23). New York: Oxford University Press.

Harford, D. (2013). Preliminary evaluation of Outcomes of Transactional Analysis Psychotherapy for Armed Forces Veterans Presenting with Post-traumatic Stress Disorder. International Journal of Transactional Analysis Research, 4(3)

Hargaden, H. \& Sills, C. (2002). Transactional Analysis: A Relational Perspective. Hove: Brunner-Routledge.

Hollanders, H. (2003). The eclectic and integrative approach. In R. Woolfe, W. Dryden, \& S. Strawbridge (Eds.), Handbook of Counselling Psychology. London: Sage. In Cooper, M. \& McLeod, J. (2011). Pluralistic counselling and Psychotherapy. London: Sage.

Hollanders, H., \& McLeod, J. (1999). Theoretical orientation and reported practice: A survey of eclecticism among counsellors in Britain. British Journal of Guidance \& Counselling, 27 (3), 405-414.

Klein, M. (1988). Envy and Gratitudev and Other Works1946 1963. London: Virago. In Howard, S. (2006). Psychodynamic Counselling in a Nutshell. London: Sage.

Larson, D. (1980). Therapeutic schools, styles and schoolism: A national survey. Journal of Humanistic Psychology, 20, 3-20. In Norcross, J. C. (2005). A Primer on Psychotherapy Integration. In J. C. Norcross \& M. R. Goldfried (Eds.), Handbook of psychotherapy integration (pp. 3-23). New York: Oxford University Press. 
Larsson, B. P. M., Broberg, A. G. \& Kaldo, V. (2013). Do psychotherapists with different theoretical orientations stereotype or prejudge each other? Journal of Contemporary Psychotherapy, 43, 169-178

McLeod, J. (2009). An Introduction to Counselling(4 ${ }^{\text {th }}$ Editiion). Maidenhead: Open University Press.

Moiso, C. \& Novellino, M. (2000). An overview of the psychodynamic school of transactional analysis. Transactional Analysis Journal,30(3), 182-187.

Norcross, J. C. (2005). A Primer on Psychotherapy Integration. In J. C. Norcross \& M. R. Goldfried (Eds.), Handbook of psychotherapy integration (pp. 3-23). New York: Oxford University Press

Norcross, J. C., Karpiak, C. P., \& Lister, K. M. (2005). What's an integrationist? A study of self-identified integrative and (occasionally) eclectic psychologists. Journal of Clinical Psychology, 61 (12), 1587-1594

Novellino, M. \& Moiso, C. (1990). The psychodynamic approach to transactional analysis. Transactional Analysis Journal,20,(3) 187-192.

Operatio, D. \& Fiske, T. (2001). Stereoptypes: Content, structures, processes and content. In R. Brown \& S. L. Gaertner (Eds.), Intergroup processes. Malden MA: Blackwell Publishers. In Larsson, B. P. M., Broberg, A. G. \& Kaldo, V. (2013). Do psychotherapists with different theoretical orientations stereotype or prejudge each other? Journal of Contemporary Psychotherapy, 43, 169-178.

Orlinsky, D., Ronnestad, M.H., Gerin, P., Willutski, U., Dazord, A., Ambuhl, H., Davis, J., Davis, M., Botermans, J-F. \& Cierpka, M. (1999). Development of Psychotherapists:
Concepts, Questions, and Methods of a Collaborative International Study. Psychotherapy Research, 9(2), 127-153.

Schiff, J \& Contributors. (1975) The Cathexis Reader: Transactional Analysis Treatment of Psychosis. New York: Harper \& Row.

Schlegel, L. (1998) What is Transactional Analysis? Transactional Analysis Journal, 28(4): 269-87

Schore, A. (1994). Affect regulation and the origin of the self: The neurobiology of emotional development. Hillsdale, $\mathrm{NJ}$ : Erlbaum. In Rolfe, W. (2000). Rethinking Feelings: Integrating the Biology of Emotion with Redecision Therapy. Journal of Redecision Therapy, 2 (1), 13-31.

Stark, M. (2000) Modes of Therapeutic Action. Northvale: Jason Aronson.

Stern, D. (1985). The interpersonal world of the infant. Basic Books: New York.

Stewart, I. (1996) Developing Transactional Analysis Counselling. London: Sage.

Stewart, I. (2000) Transactional Analysis Counselling in Action. London: Sage.

Tajfel, H. \& Turner, J. C. (1979). An Integrative Theory of Intergroup Conflict. In W. G. Austin \& S. Worchel (Eds.), The Social Psychology of Intergroup Relations. Monterey, CA: Brooks-Cole.

Widdowson, M. (2013). The process and outcome of transactional analysis psychotherapy for the treatment of depression: an adjudicated case series. Unpublished doctoral thesis. University of Leicester. 